\title{
DAYA DUKUNG TANAMAN SAWIT DAN HASIL IKUTAN LIMBAH PENGOLAHAN SAWIT SEBAGAI PAKAN TERNAK SAPI POTONG DI SUMATERA BARAT
}

\author{
Ida Indrayani, James Hellyward dan Yozil Alveni \\ Email : ida.indrayani@gmail.com (HP.081374085781)
}

\begin{abstract}
ABSTRAK
Penelitian dilakukan untuk mengetahui daya dukung kebun dan limbah sawit yang dapat dimanfaatkan sebagai pakan ternak di Sumatera Barat. Penelitian menggunakan metode desk study, berupa penelusuran data-data sekunder hasil-hasil penelitian lain yang relevan, dokumen resmi dan catatan penting pada instansi pemerintah dan instansi terkait lainnya. Hasil analisis menunjukkan daya dukung perkebunan sawit rakyat di Sumatera Barat dengan pemanfaatan hijauan, daun tanpa lidi dan pelepah sawit sebagai pakan ternak sapi secara keseluruhan dapat menampung sekitar 390.913 ekor sapi. Sementara daya dukung hasil ikutan limbah pengolahan kelapa sawit sebagai pakan ternak adalah sebesar 465.812 ekor. Dengan demikian secara keseluruhan yaitu perkebunan rakyat, negara dan swasta mampu menyediakan pakan untuk 856.725 ekor sapi. Dapat disimpulkan bahwa usaha ternak sapi potong masih mempunyai peluang untuk dikembangkan dengan memanfaatkan tanaman sawit dan hasil ikutan limbahnya sebagai pengganti pakan hijauan.
\end{abstract}

Kata kunci : kebun sawit, daya dukung, limbah sawit, pakan ternak sapi

\begin{abstract}
This study was to determine the carrying capacity of palm oil plantation and oil palm industry waste could be used as beef cattle feed in West Sumatra. This study used a desk study method, it was the activity that searched secondary data such as the results of other relevant studies, official documents and other important records in several government agencies and other relevant institutions. The analysis showed people carrying capacity of palm oil plantations folk in West Sumatra with the utilization of forage, leaves no stick and palm frond as cattle feed as a whole can accommodate about 390913 head of cattle. While carrying capacity of byproduct of palm oil processing wastes amounted to 465812 head of cattle. Overall, therefore, the palm oil plantation folk, the state and the private sector is able to provide beef cattle feed to 856725 head of cattle. It concluded that beef cattle still have a chancethe to be developed by use oil palm plantation and byproducts as a substitute for forages.
\end{abstract}

Key words: oil palm plantation, carrying capacity, oil palm industry waste, beef cattle feed

\section{PENDAHULUAN}

Usaha perkebunan di provinsi Sumatera Barat dikelola dalam 3 bentuk, yaitu: (1) perkebunan besar yang dikelola oleh BUMN, (2) perkebunan besar yang dikelola oleh perusahaan swasta besar, dan (3) perkebunan rakyat yang dikelola oleh rumah tangga dalam bentuk usaha perorangan (Dinas Perkebunan Sumatera Barat, 2006). Perkebunan rakyat mempunyai peran yang sangat strategis dalam meningkatkan peran sub sektor perkebunan kedepan. Sedangkan pada sisi produktivitas, perkebunan rakyat masih tertinggal dibandingkan perkebunan besar negara dan swasta. Rendahnya produktivitas ini disebabkan oleh kurangnya permodalan dan penguasaan teknologi, sehingga perkebunan rakyat umumnya ditandai dengan jarak tanam yang kurang teratur, tidak ada perencanaan penggantian tanaman yang teratur sesuai umur tanaman dan sebagainya (Daim, 2003).

Prospek pengembangan kelapa sawit perkebunan rakyat sangat ditentukan oleh adanya kebijakan ekonomi yang memihak kepada rakyat, agar mendorong terwujudnya kesejahteraan rakyat. Pengembangan perkebunan rakyat diyakini tidak saja meningkatkan kesejahteraan rakyat, bahkan dapat meningkatkan devisa negara, penyerapan tenaga kerja baik pada sektor industri hulu yaitu perkebunan itu sendiri maupun industri hilirnya. Komoditi kelapa sawit berbeda dengan komoditi perkebunan lain, karena memerlukan pabrik yang dekat dengan petani, agar buah yang dihasilkan dapat segera dikirim ke pabrik (dalam waktu \pm 24 jam) supaya kualitas minyak tidak mengandung asam lemak yang tinggi (Mubyarto et al., 1989).

Saat ini usaha peternakan untuk menghasilkan sapi 
bakalan (cow calf operation) dalam negeri 99 persen dilakukan oleh peternakan rakyat yang sebagian besarnya berskala kecil dengan tingkat kepemilikan 1 - 5 ekor per KK. Usaha ini biasanya terintegrasi dengan kegiatan lainnya, sehingga fungsi sapi sangat kompleks (Anonim, 2005). Oleh karenanya pembuatan kebijakan dalam pembangunan peternakan tidaklah terlepas dari kondisi objektif bahwa mayoritas masyarakat Indonesia tidak memilah-milah secara jelas antara peternakan dan pertanian umumnya. Hal ini dikarenakan sistem usahatani yang masih bersifat subsisten yang banyak oleh petani gurem.

Secara nasional, Dirjen Peternakan Departemen Pertanian, menjelaskan Indonesia masih mengalami defisit daging sapi hingga 35 persen atau 135,1 ribu ton dari kebutuhan 385 ribu ton. Sementara defisit populasi sapi diperkirakan 10,7 persen dari populasi ideal atau sekitar 1,18 juta ekor. Sementara, permintaan daging sapi, dipenuhi 70 persen dari lokal dan 30 persen impor. Permintaan pasar yang terus meningkat terhadap produk peternakan kiranya perlu perluasan areal dan peningkatan produksi untuk memenuhi kebutuhan pangan asal hewani. Percepatan pertumbuhan subsektor peternakan dalam melaksanakan fungsinya diiringi dengan strategi yang menekankan dan mengarah kepada pengembangan kawasan peternakan. Laju pertumbuhan populasi sapi cenderung lambat dan mempunyai kaitan dengan penyusutan lahan yang beralih fungsi. Agar perbaikan produktivitas yang diprogramkan dapat berjalan dengan baik maka ternak sapi membutuhkan kondisi stabil dalam arti tatalaksana memadai dan ketersediaan pakan yang berkelanjutan. Agar penurunan populasi ternak tidak terjadi dan peningkatan dapat terwujud perlu dicarikan terobosan. Salah satunya adalah melalui pemanfaatan kebun sawit. Hal ini berangkat dari kondisi masyarakat dimana di Provinsi Sumatera Barat terbentang luas areal perkebunan kelapa sawit.

Berdasarkan luasan areal perkebunan kelapa sawit, Sumatera Barat menempati urutan kedelapan areal terluas di Indonesia yaitu seluas $349.293 \mathrm{Ha}$ (Ditjenbun, 2011). Biomassa tanaman kelapa sawit maupun tanaman rerumputan dan leguminosa yang tumbuh di sekeliling tanaman pokok pada areal perkebunan tersebut sangat besar. Selain itu produk samping industri kelapa sawit juga menghasilkan biomassa yang saat ini masih menjadi limbah yang berpotensi mencemari lingkungan. Dengan pengelolaan secara baik dan benar, biomassa tersebut dapat digunakan sebagai bahan pakan yang sangat potensial untuk pengembangan ternak sapi. Ternak dapat berproduksi dan/atau berkembang biak dengan memanfaatkan biomassa gulma dan limbah tanaman kelapa sawit. Sebagian kecil atau beberapa ternak dapat dimanfaatkan sebagai tenaga kerja untuk mengangkut tandan buah segar (TBS) ke tepi jalan perkebunan, dan selanjutnya diangkut dengan menggunakan kendaraan bermotor. Kotoran ternak (manure dan urine) bersama sisa pakan dapat diolah menjadi pupuk organik yang dapat meningkatkan kesuburan tanah yang diperlukan bagi tanaman kelapa sawit. Dari timbal balik nilai tambah antara usaha perkebunan kelapa sawit dengan usaha ternak (sapi), dapat disebut sebagai simbiose sapi-sawit. Berdasarkan beberapa uraian kondisi saat ini (existing condition) maka dapat diambil perumusan masalah sebagai berikut:

1. Laju pertumbuhan populasi sapi cenderung lambat, sementara permintaan pasar terus meningkat.

2. Produksi daging sapi sebagian besar (99\%) dilakukan oleh peternakan rakyat dengan skala usaha antara 1-5 ekor sapi sehingga secara ekonomis tidak menguntungkan, ditambah lagi dengan sistem usaha yang bersifat subsisten.

3. Lahan yang tersedia belum optimal pemanfaatannya karena hanya difungsikan untuk satu jenis usaha tani walaupun sebenarnya bisa dimanfaatkan untuk usahatani ternak secara terintegratif. Berdasarkan uraian kondisi yang ada maka perlu dilihat berapa besar potensi pengembangan ternak sapi melalui sistem integrasi dengan perkebunan kelapa sawit di Sumatera Barat. Tujuan penelitian ini adalah untuk mengetahui daya dukung kebun dan limbah sawit yang dapat dimanfaatkan sebagai pakan ternak di Sumatera Barat.

\section{MATERI DAN METODE}

Penelitian ini mencakup wilayah Provinsi Sumatera Barat, ditetapkan secara purposive, dimana provinsi Sumatera Barat merupakan salah satu Provinsi yang sedang menggiatkan program pemeliharaan ternak sapi yang diintegrasikan dengan perkebunan kelapa sawit.

\section{Metode Penelitian}

Penelitian ini menggunakan metode desk study yang berupa kegiatan penelusuran data-data sekunder dari hasil-hasil penelitian lain yang relevan, dokumen resmi dan catatan-catatan penting lain pada beberapa instansi pemerintah dan instansi terkait lainnya, dimana terlebih dahulu diidentifikasi daerah-daerah yang potensial untuk pengembangan usaha ternak sapi dengan perkebunan kelapa sawit. Setelah itu diidentifikasi jumlah ternak sapi dan luas lahan kebun sawit untuk masing-masing daerah.

\section{Fokus Kajian/Analisis}

Kajian/analisis difokuskan untuk menjawab permasalahan yang dirumuskan yaitu: daya dukung 
limbah sawit sebagai pakan ternak sapi terhadap perkembangan peternakan sapi potong di Sumatera Barat, maka fokus analisis meliputi :

1. Identifikasi Kabupaten atau Kota yang ada di Sumatera Barat yang memiliki areal perkebunan kelapa sawit

2. Berdasarkan Kabupaten atau Kota yang sudah diidentifikasi, selanjutnya diidentifikasi luas kebun sawit yang meliputi :

a. Perkebunan yang dikelola oleh rakyat

b. Perkebunan yang dikelola PTPN

c. Perkebunan yang dikelola Swasta

3. Kemudian diukur potensi limbah kebun sawit yang dapat dimanfaatkan untuk pakan ternak berdasarkan luas areal lahan yang tersedia.

\section{Analisis Data}

Untuk mengetahui potensi hijauan dan limbah sawit yang dapat dimanfaatkan sebagai pakan ternak di Sumatera Barat maka dilakukan perhitungan sebagai berikut:

Tabel 1. Produk Samping Tanaman dan Olahan Kelapa Sawit Untuk Setiap Ha

\begin{tabular}{llccc}
\hline No & \multicolumn{1}{c}{ Biomasa } & $\begin{array}{c}\text { Segar } \\
(\mathrm{kg})\end{array}$ & $\begin{array}{c}\text { BK } \\
(\%)\end{array}$ & $\begin{array}{c}\text { BK } \\
(\mathrm{kg})\end{array}$ \\
\hline 1 & Daun tanpa lidi & 1.430 & 46,18 & 658 \\
2 & Pelepah & 6.292 & 26,07 & 1.640 \\
3 & Serat Perasan & 2.880 & 93,11 & 2.681 \\
4 & Lumpur sawit, solid & 4.704 & 24,07 & 1.132 \\
5 & Bungkil Kelapa Sawit & 560 & 91,83 & 514 \\
\hline
\end{tabular}

Sumber data di atas adalah Pedoman Umum Integrasi Tanaman dan Ruminansia, 2012 dengan asumsi bahwa $1 \mathrm{Ha}, 130$ pokok pohon, 1 pohon dapat menyediakan pelepah sejumlah 22 per tahun, 1 pelepah, bobot 2,2 kg (hanya 1/3 bgn yang dimanfaatkan), bobot daun per pelepah $0,5 \mathrm{~kg}$ $1.000 \mathrm{~kg}$ TBS menghasilkan: $250 \mathrm{~kg}$ minyak sawit, 294 lumpur sawit, $180 \mathrm{~kg}$ serat perasan dan $35 \mathrm{~kg}$ bungkil kelapa sawit (Jalaludin et al, 1991b). Produksi minyak sawit 4 ton per Ha per tahun (Liwang, 2003), Sementara Rata-rata produksi hijauan di bawah kelapa sawit mengacu pada Batu Bara et al. (1999), dimana kelapa sawit umur 5-10 tahun produksinya adalah 10,479 ton ha/tahun dan pohon kelapa sawit umur 10-20 tahun adalah 14,827 ton ha/tahun. Kebutuhan bahan kering pakan per ekor sapi dewasa ; 2.5\%$3.5 \%$ dari bobot badan. Jika berat sapi $200 \mathrm{~kg}$ (sapi lokal) maka kebutuhan bahan kering pakan $2.555(\mathrm{~kg} /$ tahun).

\section{HASIL DAN PEMBAHASAN}

Pengembangan sistem integrasi tanaman ternak (sapi) bertujuan untuk: 1) mendukung upaya peningkatan kandungan bahan organik lahan pertanian melalui penyediaan pupuk organik yang memadai,2) mendukung upaya peningkatan produktivitas tanaman, 3) mendukung upaya peningkatan produksi daging dan populasi ternak sapi, dan 4) meningkatkan pendapatan petani atau pelaku pertanian.

\section{Keragaan Perkebunan Sawit di Provinsi Suma- tera Barat}

Provinsi Sumatera Barat saat ini sedang giat mengembangkan perkebunan kelapa sawit, baik oleh perkebunan swasta, perkebunan negara maupun perkebunan rakyat. Sumatera Barat mempunyai lahan perkebunan kelapa sawit sebesar 367.094 Ha dimana 187.449 Ha merupakan Perkebunan Rakyat (PR), 7.836 Ha Perusahaan Negara (PTP) dan 171.809 Ha Perkebunan Besar Swasta Nasional (PBSN). Kondisi 5 tahun terakhir, luas kebun sawit di Sumatera Barat mengalami peningkatan dari tahun ke tahun. Berikut data luas Kebun Sawit di Provinsi Sumatera Barat dari tahun 2009 hingga tahun 2013.

Tabel 3 menunjukkan bahwa terjadi peningkatan luas lahan perkebunan kelapa sawit di Sumatera Barat selama 5 tahun terakhir dari tahun 2009 hingga 2013 sebesar 6,6\%. Sementara jumlah produksi kelapa sawit meningkat dengan peningkatan yang lebih besar, dimana produksi tahun 2009 sebesar 600.969 ton dan tahun 2013 menjadi 999.074 ton atau meningkat sebesar $66,2 \%$. Hal ini mengindikasikan bahwa pengembangan SISKA di Sumatera Barat memiliki peluang yang cukup besar dengan memanfaatkan sumber hijauan pakan dari perkebunan kelapa sawit tersebut. Berdasarkan luas areal kebun sawit pada masing-masing Kabupaten di Sumatera Barat, maka terdapat 7 wilayah sentra kebun sawit yaitu Kabupaten Pasaman Barat, Kabupaten Dharmasraya, Kabupaten Pesisir Selatan, Solok Selatan, 50 Kota, Agam dan Sijunjung, dengan luas areal perkebunan sawit sebagai berikut :

Berdasarkan luasan areal perkebunan kelapa sawit yang terdapat di Sumatera Barat, maka pemanfaatan lahan perkebunan kelapa sawit untuk peternakan sapi potong secara terintegrasi sangat memungkinkan. Dalam Master Plan Percepatan Pembangunan Ekonomi Tahun 2012-2025 disebutkan bahwa potensi daya saing perkebunan Sumatera Barat berada pada perkebunan sawit, dan apabila dilihat berdasarkan wilayahnya, maka potensi daya saing perkebunan kelapa sawit itu paling besar pada wilayah Kabupaten Pasaman Barat dan Kabupaten Dharmasraya.

Sementara itu, jumlah populasi sapi potong, Pesisir Selatan menempati urutan pertama dengan populasi sapi potong terbesar di Sumatera Barat yaitu 77.579 ekor. Namun jika dilihat secara keseluruhan, Populasi sapi potong di provinsi Sumatera Barat 5 
Tabel 2. Luas Areal dan Produksi Perkebunan Menurut Status Pengusahaan di Provinsi Sumatera Barat

\begin{tabular}{|c|c|c|c|c|c|c|c|c|}
\hline \multirow{2}{*}{ Tahun } & \multicolumn{4}{|c|}{ Luas (ha) } & \multicolumn{4}{|c|}{ Produksi (ton) } \\
\hline & PR & PTP & PBSN & Jumlah & PR & PTP & PBSN & Jumlah \\
\hline 2009 & 170.092 & 7.836 & 166.423 & 344.351 & 131.388 & 18.225 & 451.356 & 600.969 \\
\hline 2010 & 173.766 & 7.836 & 171.809 & 353.411 & 394.472 & 18.359 & 497.699 & 910.530 \\
\hline 2011 & 176.495 & 7.836 & 171.809 & 356.140 & 383.280 & 18.263 & 521.237 & 922.780 \\
\hline 2012 & 178.384 & 7.836 & 171.809 & 358.029 & 383.280 & 21.263 & 536.936 & 941.579 \\
\hline 2013 & 187.449 & 7.836 & 171.809 & 367.094 & 440.775 & 21.263 & 536.936 & 999.074 \\
\hline
\end{tabular}

Sumber : Dinas Perkebunan Provinsi Sumatera Barat, 2013

Tabel 3. Luas Areal dan Produksi Perkebunan Kelapa Sawit Daerah Sentra di Sumatera Barat

\begin{tabular}{|c|c|c|c|c|c|c|c|c|c|}
\hline \multirow{2}{*}{ No } & \multirow{2}{*}{ Kabupaten } & \multicolumn{4}{|c|}{ Luas (ha) } & \multicolumn{4}{|c|}{ Produksi (ton) } \\
\hline & & PR & PTP & PBSN & Jumlah & $\mathrm{PR}$ & PTP & PBSN & Jumlah \\
\hline 1 & Pasaman Barat & 96.583 & 3.256 & 59.176 & 159.015 & 223.890 & 9.951 & 198.585 & 432.426 \\
\hline 2 & Dharmasraya & 30.082 & - & 39.800 & 69.882 & 85.765 & - & 129.789 & 215.554 \\
\hline 3 & Pesisir Selatan & 22.090 & - & 23.977 & 46.067 & 33.412 & - & 58.760 & 92.172 \\
\hline 4 & Solok Selatan & 3.383 & 3.554 & 27.870 & 34.807 & 20.955 & 10.512 & 83.260 & 114.727 \\
\hline 5 & 50 Kota & 18.069 & 1.026 & 1.214 & 20.309 & 36.478 & 900 & 3.795 & 41.173 \\
\hline 6 & Agam & 1.272 & - & 15.183 & 16.455 & 2.771 & - & 48.261 & 51.032 \\
\hline 7 & Sijunjung & 10.781 & - & 4.589 & 15.370 & 25.765 & & 14.486 & 40.251 \\
\hline
\end{tabular}

Tabel 4. Populasi Sapi Potong di Provinsi Sumatera Barat Tahun 2009-2013

\begin{tabular}{cc}
\hline Tahun & Populasi Sapi Potong \\
\hline 2009 & 393269 \\
2010 & 412071 \\
2011 & 259423 \\
2012 & 280235 \\
2013 & 249135 \\
\hline
\end{tabular}

Sumber : Dinas Peternakan Provinsi Sumatera Barat, 2013

Tabel 5. Populasi Sapi Potong Wilayah Sentra Kebun Sawit di Sumatera Barat Tahun 2013

\begin{tabular}{clc}
\hline No. & Kabupaten & Populasi Sapi Potong \\
\hline 1 & Pasaman Barat & 13.438 \\
2 & Dharmasraya & 26.184 \\
3 & Pesisir Selatan & 77.539 \\
4 & Solok Selatan & 8.667 \\
5 & 50 Kota & 28.471 \\
6 & Agam & 27.442 \\
7 & Sijunjung & 14.701 \\
& Total & 167.971 \\
\hline
\end{tabular}

Sumber : Dinas Peternakan Provinsi Sumatera Barat, 2013

tahun terakhir (2009-2013) menunjukkan penurunan (Tabel 5).

\section{Potensi Perkebunan dan Limbah Sawit Sebagai Pakan Ternak Sapi}

Integrasi ternak sapi dengan perkebunan kelapa sawit dalam system dan usaha agribisnis dikembangkan dengan pendekatan Low External Input Agricilture System (LEISA), dimana terjadi ketergantungan antara kegiatan tanaman dan ternak. Hasil ikutan tanaman kelapa sawit dan hasil ikutan limbah pengolahan kelapa sawit berpeluang untuk digunakan sebagai pakan ternak sapi. Sementara hasil kotoran ternak dan sisa pakan serta hasil panen yang tidak dapat digunakan untuk pakan dapat didekomposisi menjadi kompos sebagai penyedia unsur hara untuk meningkatkan kesuburan lahan.

\section{Potensi Hijauan, Daun Sawit, dan Pelepah}

Hannafi (2007) menyatakan produk hijauan antar Tanaman (HAT) adalah vegetasi yang tumbuh liar diantara lahan perkebunan kelapa sawit, baik yang tumbuh liar diantara lahan perkebunan kelapa sawit, baik yang tumbuh liar di sela perkebunan sawit (tanaman pengganggu) ataupun beberapa jenis leguminosa atau rerumputan yang tumbuh seperti digitaria milanjiana, Stylosanthes guianensis, Paspalum notatum, dan Arachis glabarata yang menghasilkan produksi yang lebih tinggi. Rata-rata produksi hijauan di bawah kelapa sawit 5-10 tahun adalah 10,479 ton ha/tahun dan pohon kelapa sawit umur 10-20 tahun adalah 14,827 ton ha/tahun (Batu Bara, et al.,1999). Kebutuhan bahan kering pakan per ekor sapi dewasa 2,5\%-3,5\% dari bobot badan. Jika berat sapi $200 \mathrm{~kg}$ (sapi lokal) maka kebutuhan bahan kering pakan per ekor sapi $2.555 \mathrm{~kg} /$ tahun (Pedoman Umum Integrasi Tanaman dan Ruminansia, 2012). Jika satu hektar lahan sawit mampu menghasilkan 130 pokok pohon, 1 pohon dapat menyediakan pelepah sejumlah 22 per tahun, 1 pelepah, bobot 2,2 kg (hanya $1 / 3$ bgn yang dimanfaatkan), bobot daun per pelepah $0,5 \mathrm{~kg}$, maka 1 ha lahan dapat menghasilkan $1.430 \mathrm{~kg}$ daun tanpa lidi dan $6.292 \mathrm{~kg}$ pelepah dalam bentuk segar. Sedangkan dalam bentuk kering menjadi 658 $\mathrm{kg}$ daun tanpa lidi dan $1.640 \mathrm{~kg}$ pelepah. Dengan demikian lahan sawit rakyat mampu menmpung jumlah sapi di tiap Kabupaten sebagai berikut: 
Tabel 6. Daya Dukung Perkebunan Sawit Rakyat Sebagai Pakan Sapi Potong

\begin{tabular}{llrrrr}
\hline & & \multicolumn{4}{c}{ Daya Dukung } \\
\cline { 3 - 6 } No & Kabupaten & Hijauan & $\begin{array}{c}\text { Daun } \\
\text { tanpa lidi }\end{array}$ & Pelepah & Jumlah \\
\cline { 3 - 6 } & Pasaman Barat & 138.643 & 24.873 & 61.995 & 225.511 \\
2 & Dharmasraya & 43.182 & 7.747 & 19.309 & 70.238 \\
3 & Pesisir Selatan & 31.710 & 5.689 & 14.179 & 23.039 \\
4 & Solok Selatan & 4.856 & 871 & 2.171 & 7.898 \\
5 & 50 Kota & 25.938 & 4.653 & 11.598 & 42.189 \\
6 & Agam & 1.826 & 328 & 816 & 2.970 \\
7 & Sijunjung & 15.476 & 2.776 & 816 & 19.068 \\
& Total & 233.092 & 46.937 & 110.884 & 390.913 \\
\hline
\end{tabular}

Sumber : Hasil Olah Data Penelitian

Pada Tabel 3 terlihat bahwa daya dukung perkebunan sawit rakyat di Sumatera Barat dengan pemanfaatan hijauan, daun tanpa lidi dan pelepah sawit sebagai pakan ternak sapi secara keseluruhan dapat menampung sekitar 390.913 ekor sapi. Dengan kata lain daya dukung 1 ha kebun sawit rakyat adalah untuk 1,6 ekor sapi dewasa. Hasil analisis juga menunjukkan dengan pemanfaatan hijaun yang ada di kebun sawit rakyat dapat menampung sudah bisa menampung sekitar 233.092 ekor ternak, dimana angka ini melebihi angka populasi sapi potong di ke tujuh wilayah tersebut.

\section{Potensi Hasil Ikutan Limbah Pengolahan Ke- lapa Sawit}

Berbagai produk ikutan industri kelapa sawit yang dapat dimanfaatkan untuk menghasilkan bahan pakan alternatif untuk sapi potong antara lain adalah pelepah dan daun sawit, serat perasan, lumpur sawit (solid) dan bungkil kelapa sawit. Selain itu juga ada tandan buah kosong, namun kandungan serat kasarnya sangat tinggi dan nutrisinya masih rendah (pedoman umum integrasi tanaman dan ruminansia, 2012).

Tabel 7. Produk Samping Tanaman dan Olahan Kelapa Sawit Untuk Setiap Ha

\begin{tabular}{rlccr}
\hline No & \multicolumn{1}{c}{ Biomasa } & Segar $(\mathrm{kg})$ & BK (\%) & BK (kg) \\
\hline 1 & Daun tanpa lidi & 1.430 & 46,18 & 658 \\
2 & Pelepah & 6.292 & 26,07 & 1.640 \\
3 & Serat Perasan & 2.880 & 93,11 & 2.681 \\
4 & Lumpur sawit, solid & 4.704 & 24,07 & 1.132 \\
5 & Bungkil Kelapa Sawit & 560 & 91,83 & 514 \\
\hline \multicolumn{4}{l}{ Sumber : Pedoman Umum Integrasi Tanaman dan Ruminansia, 2012 }
\end{tabular}

Selain Perkebunan Rakyat, kebun sawit di Provinsi Sumatera Barat juga terdiri dari kebun negara dan swasta. Dilihat dari luasnya kebun sawit milik Negara dan swasta tersebut maka daya dukung hasil ikutan limbah pengolahan kelapa sawit sebagai pakan ternak adalah sebesar 465.812 ekor atau dengan kata lain dari biomasa yang dihasilkan untuk setiap hektarnya mampu menyediakan pakan untuk 2,6
Tabel 8. Daya Dukung Lahan Sawit Perkebunan Negara dan Swasta Nasional Sebagi Pakan Sapi Potong

\begin{tabular}{lrrrr}
\hline No & Kabupaten & $\begin{array}{c}\text { Perusahaan } \\
\text { Negara }\end{array}$ & $\begin{array}{c}\text { Perusahaan Swasta } \\
\text { Nasional }\end{array}$ & Jumlah \\
\hline 1 Pasaman Barat & 8.443 & 153.441 & 161.884 \\
2 Dharmasraya & - & 103.200 & 103.200 \\
3 Pesisir Selatan & - & 62.171 & 62.171 \\
4 Solok Selatan & 9.215 & 72.266 & 81.481 \\
5 50 Kota & 2.660 & 3.148 & 5.808 \\
6 Agam & - & 39.369 & 39.369 \\
7 Sijunjung & - & 11.899 & 11.899 \\
& Total & 20.318 & 445.494 & 465.812 \\
\hline
\end{tabular}

Sumber : Hasil Olah Data Penelitian

ekor sapi dewasa. Dengan demikian potensi daya dukung keseluruhan yaitu perkebunan rakyat, negara dan swasta adalah 856.725 ekor. Dengan demikin berdasarkan data populasi sapi potong di tujuh Kabupaten diatas yang baru berjumlah 167.971 ekor, maka peluang pengembangan sapi potong di Sumatera Barat dengan integrasi sapi-sawit masih cukup besar.

\section{SIMPULAN}

Daya dukung perkebunan sawit rakyat di Sumatera Barat dengan pemanfaatan hijauan, daun tanpa lidi dan pelepah sawit sebagai pakan ternak sapi secara keseluruhan dapat menampung sekitar 390.913 ekor sapi. Sementara daya dukung hasil ikutan limbah pengolahan kelapa sawit sebagai pakan ternak adalah sebesar 465.812 ekor. Dengan demikian secara keseluruhan yaitu perkebunan rakyat, negara dan swasta mampu menyediakan pakan untuk 856.725 ekor sapi.

\section{DAFTAR PUSTAKA}

Anonim. 2005. Prospek dan Arah Pengembangan Agribisnis Sapi. Jakarta - Deptan.

Batubara, A., I. Kasup, A. A. Kesma. A. Irfan, H. Simanjuntak dan Harahap. 1999. Kajian Integrasi Penggemukan Ternak Sapi Potong di Lahan Perkebunan Kelapa Sawit.

Daim, Chamidun. 2003. Pengembangan Kemitraan dan Dukungan Pendanaannya di Bidang Perkebunan. IPB. Bogor.

Dinas Perkebunan Provinsi Sumatera Barat. 2013.Laporan Tahunan Dinas Perkebunan Provinsi Sumatera Barat Tahun 2013. Padang.

Direktorat Jenderal Perkebunan. 2011. Statistik Perkebunan 2009-2011. Sekretariat Direktorat Jenderal Perkebunan.

Direktorat Pakan Ternak. 2012. Pedoman Umum Integrasi Tanaman-Ruminansia Tahun 2012. Jakarta.

Mubyarto, 1989. Masalah dan Prospek Komoditi Perkebunan, UGM-Press. Yogyakarta 